\title{
Soil and Leaf Micronutrient Composition in Contrasting Habitats in Podzolized Sands of the Amazon Region
}

\author{
María Antonieta Sobrado \\ Laboratorio de Biología Ambiental de Plantas, Departamento de Biología de Organismos, Universidad Simón Bolívar, Caracas, \\ Venezuela. \\ Email:msobrado@usb.ve
}

Received July $5^{\text {th }}, 2013$; revised August $5^{\text {th }}, 2013$; accepted September $1^{\text {st }}, 2013$

Copyright (C) 2013 María Antonieta Sobrado. This is an open access article distributed under the Creative Commons Attribution License, which permits unrestricted use, distribution, and reproduction in any medium, provided the original work is properly cited.

\begin{abstract}
Plant macronutrient distribution in podzolized sands of the Amazon caatinga has received attention in several studies; however, the distribution of micronutrients has not been assessed. Soil micronutrient availability has been hypothesized to reflect contrasting habitat characteristics as well as fundamental differences in substrate, and leaf micronutrient composition may reflect the macronutrient content needed to maintain balance for leaf cell functions. In this study, soil and leaf samples were obtained in a toposequence (valley, slope, and mound). Available soil micro- and macronutrients as well as total leaf content were measured by inductively coupled plasma-atomic emission spectrometer and mass spectroscopy. Soil Zn $\left(<1.41 \mathrm{mg} \cdot \mathrm{kg}^{-1}\right)$ and $\mathrm{B}\left(<0.31 \mathrm{mg} \cdot \mathrm{kg}^{-1}\right)$ as well as $\mathrm{Cu}\left(<1.33 \mathrm{mg} \cdot \mathrm{kg}^{-1}\right)$ levels were very low. Soil Mn was low in the valleys and slopes $\left(0.62-0.87 \mathrm{mg} \cdot \mathrm{kg}^{-1}\right)$, but higher in the mound $\left(6.59 \mathrm{mg} \cdot \mathrm{kg}^{-1}\right)$. Soil Fe (11.48 $21.13 \mathrm{mg} \cdot \mathrm{kg}^{-1}$ ) was well above the critical level in all of the habitats. Leaf micronutrients $\mathrm{Cu}, \mathrm{B}, \mathrm{Zn}$, and Fe were below the critical levels for tropical crops of $3-7,20-70,15-20$, and $72 \mathrm{mg} \cdot \mathrm{kg}^{-1}$, respectively. Leaf $\mathrm{Mn}\left(<188 \mathrm{mg} \cdot \mathrm{kg}^{-1}\right)$ and $\mathrm{Al}\left(<50 \mathrm{mg} \cdot \mathrm{kg}^{-1}\right)$ were below the accumulators level. A strong relationship between leaf micro- and macronutrients suggests the maintenance of a homeostatic elemental composition, which may favour photosynthetic function. Therefore, the local distribution of species may be shaped by their abilities to maintain a balance of micronutrient collected through roots under critically low levels of available $\mathrm{Zn}, \mathrm{B}$, and $\mathrm{Cu}$ whilst excluding potentially deleterious ions of $\mathrm{Mn}$, $\mathrm{Fe}$, and $\mathrm{Al}$.
\end{abstract}

Keywords: Acid Soils; Amazon Caatinga; Ionome; Leaf Nutrient Homeostasis; Micronutrients; Toxic Elements

\section{Introduction}

Micronutrient availability and cycles in tropical areas are poorly understood, even though such information is imperative for a thorough understanding of the complexities of major element cycles in these habitats [1]. Very low micronutrient levels have been found in tropical natural areas that have severely impoverished macronutrient levels as well $[2,3]$. The micronutrient distribution is particularly relevant in a situation of deficiency, when alternative plant developmental processes and biochemical pathways may be prioritized as a function of growth, development, metabolic status, and environment [4]. Thus, the interactions among elements within plant cells tend to reflect the regulatory network involved in the homeostasis of the ionome $[5,6]$. These interactions and the balance of ions in plant tissue may have an ecophysiological significance as well, which requires further investigation in order to gain insight into these processes.
The upper Rio Negro in the Amazon basin experiences high yearly rainfall levels, as well as differential soil types and topographical conditions. Consequently a mosaic of vegetation types is featured. The Amazon caatinga complex is located on lowland areas with infertile, bleached, sandy podzols surrounded by low rolling hills containing oxisol soils [7]. A clear toposequence (valleyslopes-domes) with gradual changes is found within the caatinga, which forms a complex community continuum [8]. The macronutrient concentration and fluxes in soil organic matter as well as the organic matter turnover rates have paramount importance for the maintenance of fertility across the caatinga habitats $[9,10]$. Historically, plant macronutrient distribution has received most attention for this vegetation type $[9,11,12]$, and the distribution of micronutrients has not been assessed previously. In this study, it was hypothesized that soil micronutrient availability may reflect contrasting habitat characteristics, 
and that the leaf micronutrient composition of species thriving in different habitats may reflect the macronutrient content at particular sites in order to maintain the ion balance for leaf cell functions. In this study, the micronutrient composition of soils and leaves of dominant tree species within the toposequence of the caatinga vegetation was assessed. In particular, differences in the dominant species thriving in each of these contrasting sites were determined.

\section{Material and Methods}

\subsection{Study Site and Species}

The study site is located near the confluence of the Rio Negro and the Casiquiare River in southern Venezuela near the village of San Carlos de Rio Negro ( $1^{\circ} 54^{\prime} \mathrm{N}$, $\left.67^{\circ} 3^{\circ} \mathrm{W}, 119 \mathrm{~m} \mathrm{ASL}\right)$. The area features a mean annual temperature of $26^{\circ} \mathrm{C}$ and mean annual rainfall of 3600 $\mathrm{mm}$. Podzol soils of the caatinga have developed probably from Precambrian sandstone, and the top soil contains medium-textured sand mixed with humus [7]. In the valleys, soils are water saturated and dominated by Eperua leucantha Benth (Caesalpiniaceae; "yaguacana" forest). The slopes (ecotone) are dominated by Micranda sprucei (Müll.Arg.) R. E. Schultes (Euphorbiaceae; “cunuri" forest), which maintain a relatively stable water table, and the slightly higher sandy mounds suffer droughts during short rainless periods [7,8]. The species selected for this study were E. leucantha and M. sprucei from the close, high stature forests (18 - $25 \mathrm{~m}$; valley and slopes). The less fertile and drought-prone tops of the sandy mounds contain tree species of low stature and open arrangement ("bana" forest; 5 - $7 \mathrm{~m}$ ). At this site, Pachira sordida (R.E. Schult.) W.S. Alverson (syn. Rodognaphalopsis discolor A. Robyns), (Malvaceae) and Remijia morilloi Steyerm (Rubiaceae) are the dominant species. The use of dominant species has proven to be ecological indicators of typical habitats within the upper Rio Negro vegetation [13]. From the valley towards the slopes and sandy mounds, leaves become more scleromorphic, and those on sandy mounds are relatively more drought-resistant $[14,15]$.

\subsection{Leaf and Soil Sampling}

For each species, three mature trees with a fully exposed top canopy were selected and tagged for soil and plant collection during August 2010 [13]. Four soil samples consisting of sand and humus were collected from $0-5$ $\mathrm{cm}$ depth under each tree (E. leucantha and $M$. sprucei) or under a pair of trees (P. sordida and $R$. morilloi). The four samples were pooled in the field after all visible plant pieces were removed by hand. Each sample consisting of sand and humus was dehydrated at room temperature, ground, homogenized, and sieved though 2 mmmesh. A total of three pooled soil samples were analyzed in each of the three habitats. Three top canopy branches were detached in each tagged tree and adult leaves with a healthy appearance were collected and pooled. Leaf blade samples, excluding major veins, were oven dried to a constant weight at $60^{\circ} \mathrm{C}$ and ground prior to performing the analysis. A total of three pooled leaf blade samples were analyzed for each plant species.

\subsection{Soil Analysis}

Soil subsamples were used for the following analyses: soil $\mathrm{pH}$ was measured in a slurry of $5 \mathrm{~g}$ soil in distilled water at a ratio of 1:1. Buffer $\mathrm{pH}$ or acidity was estimated in subsamples of $5 \mathrm{~g}$ by using Mehlich 3 as a buffer solution to estimate the acidity. Organic content (OM) was determined by weight loss on ignition in subsamples of approximately $5-7 \mathrm{~g}$. Soil exchangeable micronutrients ( $\mathrm{Fe}, \mathrm{Mn}, \mathrm{Zn}, \mathrm{B}$, and $\mathrm{Cu}$ ) and macronutrients $(\mathrm{P}, \mathrm{Ca}$, $\mathrm{K}$, and $\mathrm{Mg}$ ) as well as $\mathrm{Al}$ were measured by using an Inductively Coupled Plasma-Atomic Emission Spectrometer (ICP-AES, Varian, Model 730-ES, Palo Alto, California, USA). The Mehlich 3 soil test extract was used in subsamples for element extraction, except for B, which was extracted in hot water. Soil subsamples weighing 10 $\mathrm{g}$ were used for B extraction and a subsample measuring $2.5 \mathrm{~cm}^{3}$ was used for the other elements. Soil cation exchange capacity (CEC) was estimated from the sum of soil acidity (see above) and the $\mathrm{Ca}, \mathrm{Mg}$, and $\mathrm{K}$ content and expressed as meq/100 $\mathrm{g}$. The percentage of base saturation (BS) was calculated as the percentage of soil CEC occupied by $\mathrm{Ca}, \mathrm{Mg}$, and $\mathrm{K}$. Detailed soil analysis procedures have been previously described [16]. The soil $\mathrm{N}$ and $\mathrm{C}$ composition analysis was performed at the Stable Isotope Research Facility for Ecological Research (SIRFER), University of Utah (Salt Lake City, USA).

\subsection{Leaf Analysis}

Leaf samples were analyzed for the same elements measured in the soils using the ICP-AES as well. A total of $0.2 \mathrm{~g}$ per leaf sample was muffled and ashed, dissolved in $2 \mathrm{ml}$ of $5 \mathrm{~N} \mathrm{HCL}$, and heated at $200^{\circ} \mathrm{C}$ for $2 \mathrm{~min}$. Subsequently, the samples were brought to a $10 \mathrm{ml}$ volume with de-ionized water and centrifuged at $2000 \mathrm{rpm}$ for 4 minutes to precipitate carbon rests prior to performing ICP measurements. The procedure followed is described elsewhere [17]. The leaf $\mathrm{N}$ and $\mathrm{C}$ compositions of these species have been previously reported $[14,18]$.

\subsection{Statistical Analysis}

Measurements were performed on independent replicates taken randomly, and data are presented as mean \pm standard error. The normality of distributions was assessed 
using the Kolmogorov-Smirnov test and equality of variance using Levene's test. When the data were normally distributed with equal variance, one-way analysis of variance (ANOVA) was used and multiple comparisons were made with the Holm-Sidak test. Conversely, if data normality and/or equal variance tests failed, then an ANOVA-on-ranks test was used and statistical differences were determined with the Tukey test. Pearson correlation coefficients were used to quantify the relationships between micro- and macro-nutrients. Significance level was set at $\mathrm{P}<0.05$ and the analyses were performed using SigmaStats 3.1 software for Windows (Systat Software, Inc., Chicago, USA).

\section{Results}

\subsection{Soil Analysis}

The results of soils analysis are shown in Table 1. Soil $\mathrm{pH}$ was significantly different across sites, with the lowest $(3.33 \pm 0.06)$ and highest $(4.22 \pm 0.03)$ values found in the waterlogged valley bottoms and sandy mounds, respectively $(\mathrm{p}<0.05)$. The $\mathrm{pH}$ was negatively related to $\mathrm{OM}(\mathrm{r}=-0.88 ; \mathrm{P}<0.001)$ and CEC $(\mathrm{r}=-0.87 ; \mathrm{P}<$ $0.001)$. Additionally, $\mathrm{pH}$ was also negatively related to

Table 1. Soil characteristics and nutrient composition.

\begin{tabular}{cccc}
\hline & \multicolumn{3}{c}{ Toposequence sites } \\
\cline { 2 - 4 } & Valley & Slope & Mound \\
\hline $\mathrm{pH}$ & $3.33 \pm 0.06 \mathrm{c}$ & $4.01 \pm 0.04 \mathrm{~b}$ & $4.22 \pm 0.03 \mathrm{a}$ \\
$\mathrm{OM}(\%)$ & $19.2 \pm 4.4 \mathrm{a}$ & $7.5 \pm 0.7 \mathrm{~b}$ & $6.6 \pm 1.2 \mathrm{~b}$ \\
$\mathrm{CEC}(\mathrm{meq} / 100 \mathrm{~g})$ & $20.6 \pm 0.1 \mathrm{a}$ & $17.9 \pm 0.4 \mathrm{~b}$ & $14.4 \pm 0.8 \mathrm{c}$ \\
$\mathrm{BS}(\%)$ & $2.4 \pm 0.2 \mathrm{~b}$ & $2.9 \pm 0.1 \mathrm{~b}$ & $11.9 \pm 0.3 \mathrm{a}$ \\
$\mathrm{Fe}\left(\mathrm{mg} \cdot \mathrm{kg}^{-1}\right)$ & $14.36 \pm 0.06 \mathrm{~b}$ & $11.48 \pm 0.79 \mathrm{~b}$ & $21.13 \pm 0.58 \mathrm{a}$ \\
$\mathrm{Mn}\left(\mathrm{mg} \cdot \mathrm{kg}^{-1}\right)$ & $0.87 \pm 0.08 \mathrm{~b}$ & $0.62 \pm 0.14 \mathrm{~b}$ & $6.59 \pm 1.83 \mathrm{a}$ \\
$\mathrm{Zn}\left(\mathrm{mg} \cdot \mathrm{kg}^{-1}\right)$ & $1.41 \pm 0.03 \mathrm{a}$ & $0.99 \pm 0.07 \mathrm{~b}$ & $1.35 \pm 0.14 \mathrm{ab}$ \\
$\mathrm{B}\left(\mathrm{mg} \cdot \mathrm{kg}^{-1}\right)$ & $0.20 \pm 0.05$ & $0.31 \pm 0.05$ & $0.17 \pm 0.04$ \\
$\mathrm{Cu}\left(\mathrm{mg} \cdot \mathrm{kg}^{-1}\right)$ & $1.24 \pm 0.06 \mathrm{a}$ & $1.33 \pm 0.01 \mathrm{a}$ & $1.03 \pm 0.01 \mathrm{~b}$ \\
$\mathrm{Al}\left(\mathrm{mg} \cdot \mathrm{kg}^{-1}\right)$ & $290 \pm 43 \mathrm{a}$ & $159 \pm 24 \mathrm{a}$ & $62 \pm 4 \mathrm{~b}$ \\
$\mathrm{C}\left(\mathrm{g} \cdot \mathrm{kg}^{-1}\right)$ & $139 \pm 32 \mathrm{a}$ & $49 \pm 5 \mathrm{~b}$ & $35 \pm 14 \mathrm{~b}$ \\
$\mathrm{~N}\left(\mathrm{~g} \cdot \mathrm{kg}^{-1}\right)$ & $5.21 \pm 1.30 \mathrm{a}$ & $1.92 \pm 0.02 \mathrm{~b}$ & $1.08 \pm 0.04 \mathrm{c}$ \\
$\mathrm{K}\left(\mathrm{mg} \cdot \mathrm{kg}^{-1}\right)$ & $107 \pm 8.7$ & $88.5 \pm 6.1$ & $107 \pm 1.1$ \\
$\mathrm{Ca}\left(\mathrm{mg} \cdot \mathrm{kg}^{-1}\right)$ & $55.7 \pm 2.9 \mathrm{~b}$ & $77.1 \pm 0.4 \mathrm{~b}$ & $185 \pm 12 \mathrm{a}$ \\
$\mathrm{Mg}\left(\mathrm{mg} \cdot \mathrm{kg}^{-1}\right)$ & $33.0 \pm 2.9 \mathrm{~b}$ & $44.0 \pm 4.0 \mathrm{ab}$ & $63 \pm 9.2 \mathrm{a}$ \\
$\mathrm{P}\left(\mathrm{mg} \cdot \mathrm{kg}^{-1}\right)$ & $29.5 \pm 3.7 \mathrm{a}$ & $30.0 \pm 3.8 \mathrm{a}$ & $18.1 \pm 2.3 \mathrm{~b}$ \\
$\mathrm{C} / \mathrm{N}\left(\mathrm{kg} \cdot \mathrm{kg}^{-1}\right)$ & $27.2 \pm 0.5 \mathrm{~b}$ & $25.5 \pm 0.4 \mathrm{~b}$ & $32.4 \pm 1.4 \mathrm{a}$ \\
$\mathrm{N} / \mathrm{P}\left(\mathrm{kg} \cdot \mathrm{kg}^{-1}\right)$ & $171 \pm 23 \mathrm{~b}$ & $66.1 \pm 6 \mathrm{a}$ & $63.6 \pm 11 \mathrm{a}$ \\
\hline
\end{tabular}

Values are mean $\pm \mathrm{SE}$ of soil $\mathrm{pH}$ in water, organic matter $(\mathrm{OM})$, cation exchange capacity (CEC), base saturation (BS), micronutrients, and macronutrients as well as $\mathrm{C} / \mathrm{N}$ and N/P. Means followed by different letters are statistically different at $\mathrm{P}<0.05$.
$\mathrm{Al}(\mathrm{r}=-0.91 ; \mathrm{P}<0.001), \mathrm{C}(\mathrm{r}=-0.92 ; \mathrm{P}<0.001), \mathrm{N}(\mathrm{r}$ $=-0.92 ; \mathrm{P}<0.001)$, and the N/P ratio $(\mathrm{r}=-0.94, \mathrm{P}<$ $0.001)$. In contrast, $\mathrm{pH}$ was positively correlated with $\mathrm{Mn}$ $(\mathrm{r}=0.60 ; \mathrm{P}<0.05)$ as well as with $\mathrm{Mg}(\mathrm{r}=0.73 ; \mathrm{P}<$ $0.05), \mathrm{Ca}(\mathrm{r}=0.77 ; \mathrm{P}<0.01)$, and consequently to BS ( $\mathrm{r}$ $=0.71 ; \mathrm{P}<0.05)$.

Soil $\mathrm{K}$ values were statistically indistinguishable among sites, ranging from 88.5 to $107 \mathrm{mg} \cdot \mathrm{kg}^{-1}$. The slopes of the toposequence had mineral concentrations (in $\mathrm{mg} \cdot \mathrm{kg}^{-1}$ ) that was statistically indistinguishable to that in the valleys: (Mn: $0.62 \pm 0.14$ vs. $0.87 \pm 0.08$; Cu: $1.33 \pm 0.01$ vs. $1.24 \pm 0.06$ ), macronutrients (P: $30 \pm 3.8$ vs. $29.5 \pm 3.7$; Ca: $77.1 \pm 0.4$ vs. $55.7 \pm 2.9)$, and $\mathrm{Al}(159 \pm 24$ vs. $290 \pm$ $43)$, respectively. Slopes and domes had statistically comparable C content $\left(49 \pm 5\right.$ vs. $\left.35 \pm 14 \mathrm{~g} \cdot \mathrm{kg}^{-1}\right)$ but lowest of that in the valley $\left(139 \pm 32 \mathrm{~g} \cdot \mathrm{kg}^{-1}\right)$, respectively. Mounds had the statistically lowest concentration of $\mathrm{Cu}$ $\left(1.03 \pm 0.01 \mathrm{mg} \cdot \mathrm{kg}^{-1}\right)$ and $\mathrm{Al}\left(62 \pm 2 \mathrm{mg} \cdot \mathrm{kg}^{-1}\right)$, and the highest $\mathrm{Mn}(6.59 \pm 1.83$ vs. $0.62 \pm 0.14$ and $0.87 \pm 0.08$ $\mathrm{mg} \cdot \mathrm{kg}^{-1}$ ) compared to slopes and valley, respectively. Similarly, mound had the lowest concentrations of the macronutrients $\mathrm{N}(1.08 \pm 0.04$ vs. $1.92 \pm 0.02$ and $5.21 \pm$ $\left.1.3 \mathrm{~g} \cdot \mathrm{kg}^{-1}\right)$ and $\mathrm{P}(18.2 \pm 2.3$ vs. $29.5 \pm 3.7$ and $30 \pm 3.8$ $\left.\mathrm{mg} \cdot \mathrm{kg}^{-1}\right)$ as well as the highest $\mathrm{C} / \mathrm{N}$ ratio $(32.4 \pm 1.4 \mathrm{vs}$. $25.5 \pm 0.4$ and $27.0 \pm 0.5 \mathrm{~kg} \cdot \mathrm{kg}^{-1}$ ) as compared to those in slopes and valley, respectively.

\subsection{Plant Analysis}

Plant analysis results are shown in Table 2. The values of $\mathrm{Fe}\left(20.6-39.5 \mathrm{mg} \cdot \mathrm{kg}^{-1}\right)$ and $\mathrm{Zn}\left(6.5-14.3 \mathrm{mg} \cdot \mathrm{kg}^{-1}\right)$ tended to decline significantly in species from the mounds ( $P$. sordida and R. morilloi) as compared to that of the valley (E. leucantha). Values of $\mathrm{Cu}(1-2.5$ $\mathrm{mg} \cdot \mathrm{kg}^{-1}$ ) were species specific. Values of B were slightly higher in E. leucantha $\left(17.4 \pm 1.2 \mathrm{mg} \cdot \mathrm{kg}^{-1}\right)$ from the valley and M. sprucei $\left(15.3 \pm 0.5 \mathrm{mg} \cdot \mathrm{kg}^{-1}\right)$ from the slope, as compared to $P$. sordida $\left(11.2 \pm 1.0 \mathrm{mg} \cdot \mathrm{kg}^{-1}\right)$ and $R$. morilloi $\left(10.6 \pm 0.3 \mathrm{mg} \cdot \mathrm{kg}^{-1}\right)$ from the mound. In contrast, Mn (43.6 - $\left.188 \mathrm{mg} \cdot \mathrm{kg}^{-1}\right)$ was relatively high in all species except $P$. sordida (mound; $12.8 \pm 3.8 \mathrm{mg} \cdot \mathrm{kg}^{-1}$ ). Differences in leaf Al concentrations (4.6 - $49.4 \mathrm{mg} \cdot \mathrm{kg}^{-1}$ ) were species specific across habitats. Regarding the macronutrients, the trend of leaf $\mathrm{N}$ and $\mathrm{P}$ was to decline from the valley towards the mounds. By contrast, leaf N/P, Ca, $\mathrm{Mg}$, and $\mathrm{K}$ were species specific and did not show a clear trend along the toposequence.

Statistically significant correlations were found between micro- and macronutrients (Table 3). Thus, $\mathrm{Fe}$ is correlated with $\mathrm{N}(\mathrm{r}=0.92 ; \mathrm{P}<0.001)$ and $\mathrm{P}(\mathrm{r}=0.62 ; \mathrm{P}$ $<0.05)$, Zn with $\mathrm{N}(\mathrm{r}=0.94 ; \mathrm{P}<0.001)$ and $\mathrm{P}(\mathrm{r}=0.68$; $\mathrm{P}<0.01)$ and $\mathrm{B}$ with $\mathrm{N}(\mathrm{r}=0.77 ; \mathrm{P}<0.01)$ and $\mathrm{P}(\mathrm{r}=$ 0.59 ; $\mathrm{P}<0.05)$. Similarly, Mn was correlated with $\mathrm{Ca}(\mathrm{r}$ $=0.56 ; \mathrm{P}<0.05)$ and $\mathrm{Mg}(\mathrm{r}=0.63 ; \mathrm{P}<0.05)$. The set of 
Table 2. Leaf nutrient composition of the dominant species.

\begin{tabular}{ccccc}
\hline & \multicolumn{4}{c}{ Toposequence sites } \\
\cline { 2 - 5 } & Valley & Slope & \multicolumn{2}{c}{ Mound } \\
\cline { 2 - 5 } & E. leucantha & M. sprucei & P. sordida & R. morilloi \\
\hline $\mathrm{Fe}$ & $39.5 \pm 1.0 \mathrm{a}$ & $26.9 \pm 1.6 \mathrm{~b}$ & $20.6 \pm 1.6 \mathrm{c}$ & $22.9 \pm 0.3 \mathrm{c}$ \\
$\mathrm{Mn}$ & $88.5 \pm 11.1 \mathrm{~b}$ & $188 \pm 43 \mathrm{a}$ & $12.8 \pm 3.8 \mathrm{~d}$ & $43.6 \pm 6.1 \mathrm{c}$ \\
$\mathrm{Zn}$ & $14.3 \pm 1.1 \mathrm{a}$ & $7.4 \pm 04 \mathrm{~b}$ & $6.9 \pm 0.5 \mathrm{~b}$ & $6.5 \pm 0.4 \mathrm{~b}$ \\
$\mathrm{~B}$ & $17.4 \pm 1.2 \mathrm{a}$ & $15.3 \pm 0.5 \mathrm{a}$ & $11.2 \pm 1.0 \mathrm{~b}$ & $10.6 \pm 0.3 \mathrm{~b}$ \\
$\mathrm{Cu}$ & $2.5 \pm 0.1 \mathrm{a}$ & $1.0 \pm 0.1 \mathrm{~b}$ & $2.9 \pm 0.2 \mathrm{a}$ & $2.2 \pm 0.2 \mathrm{a}$ \\
$\mathrm{Al}$ & $14.9 \pm 1.9 \mathrm{~b}$ & $4.6 \pm 0.6 \mathrm{c}$ & $5.8 \pm 1.1 \mathrm{c}$ & $49.4 \pm 5.6 \mathrm{a}$ \\
$\mathrm{N}$ & $16.7 \pm 0.3 \mathrm{a}$ & $9.3 \pm 0.3 \mathrm{~b}$ & $9.1 \pm 0.5 \mathrm{~b}$ & $7.4 \pm 0.4 \mathrm{c}$ \\
$\mathrm{K}$ & $3.89 \pm 0.39 \mathrm{c}$ & $6.42 \pm 0.39 \mathrm{~b}$ & $10.0 \pm 0.69 \mathrm{a}$ & $3.20 \pm 0.29 \mathrm{c}$ \\
$\mathrm{Ca}$ & $1.57 \pm 0.08 \mathrm{~b}$ & $0.93 \pm 0.14 \mathrm{~b}$ & $3.68 \pm 0.89 \mathrm{a}$ & $1.64 \pm 0.26 \mathrm{~b}$ \\
$\mathrm{Mg}$ & $1.41 \pm 0.03 \mathrm{~b}$ & $1.28 \pm 0.06 \mathrm{~b}$ & $3.05 \pm 0.89 \mathrm{a}$ & $1.62 \pm 0.09 \mathrm{~b}$ \\
$\mathrm{P}$ & $1.15 \pm 0.03 \mathrm{a}$ & $0.84 \pm 0.01 \mathrm{~b}$ & $0.96 \pm 0.08 \mathrm{~b}$ & $0.45 \pm 0.01 \mathrm{c}$ \\
$\mathrm{N} / \mathrm{P}$ & $14.6 \pm 1.4 \mathrm{a}$ & $11.1 \pm 0.5 \mathrm{ab}$ & $9.6 \pm 0.5 \mathrm{~b}$ & $16.4 \pm 1.9 \mathrm{a}$ \\
\hline
\end{tabular}

The values are in $\mathrm{mg} \cdot \mathrm{kg}^{-1}$, except that of $\mathrm{N}, \mathrm{K}, \mathrm{Ca}, \mathrm{Mg}$ and $\mathrm{P}\left(\mathrm{g} \cdot \mathrm{kg}^{-1}\right)$ and $\mathrm{N} / \mathrm{P}\left(\mathrm{kg} \cdot \mathrm{kg}^{-1}\right)$. Values are mean $\pm \mathrm{SE}$. Means followed by different letters are statistically different at $\mathrm{P}<0.05$.

Table 3. Correlation coefficients between leaf micro- and macronutrients across species.

\begin{tabular}{cccccc}
\hline & $\mathrm{Fe}$ & $\mathrm{Mn}$ & $\mathrm{Zn}$ & $\mathrm{B}$ & $\mathrm{Cu}$ \\
\hline $\mathrm{N}$ & $\mathbf{0 . 9 2}^{\text {****}}$ & 0.11 & $\mathbf{0 . 9 4}^{\text {*** }}$ & $\mathbf{0 . 7 7}^{* *}$ & 0.16 \\
$\mathrm{~K}$ & 0.48 & 0.18 & 0.41 & 0.19 & 0.15 \\
$\mathrm{Ca}$ & -0.39 & $\mathbf{0 . 5 6}^{*}$ & 0.25 & 0.34 & $\mathbf{0 . 5 9}^{*}$ \\
$\mathrm{Mg}$ & $\mathbf{- 0 . 5 8}^{*}$ & $\mathbf{0 . 6 3}^{*}$ & 0.35 & $\mathbf{0 . 5 7}^{*}$ & $\mathbf{0 . 7 0}^{* * *}$ \\
$\mathrm{P}$ & $\mathbf{0 . 6 2}^{*}$ & 0.11 & $\mathbf{0 . 6 8}^{\text {*** }}$ & $\mathbf{0 . 5 9}^{*}$ & 0.20 \\
\hline
\end{tabular}

Significant correlations are in bold and $\mathrm{P}<0.05\left(^{*}\right), \mathrm{P}<0.01\left(^{* *}\right)$, and $\mathrm{P}<$ $0.001\left(^{* * *}\right)$.

$\mathrm{Fe}, \mathrm{Zn}$, and $\mathrm{B}$ as well as the set of $\mathrm{Mn}, \mathrm{Ca}$, and $\mathrm{Mg}$ are involved in leaf chloroplast and mitochondrial function. A negative correlation between $\mathrm{Fe}$ and $\mathrm{Mg}(\mathrm{r}=-0.58$; $\mathrm{P}$ $<0.05$ ) was consistent with its antagonic role in plants.

\section{Discussion}

Soil critical values for tropical crops of $\mathrm{Fe}(2.5-5.8$ $\left.\mathrm{mg} \cdot \mathrm{kg}^{-1}\right), \mathrm{Mn}\left(1-4 \mathrm{mg} \cdot \mathrm{kg}^{-1}\right), \mathrm{Zn}\left(3.3 \mathrm{mg} \cdot \mathrm{kg}^{-1}\right), \mathrm{B}(1-$ $\left.2.4 \mathrm{mg} \cdot \mathrm{kg}^{-1}\right)$, and $\mathrm{Cu}\left(1-2 \mathrm{mg} \cdot \mathrm{kg}^{-1}\right)$ were previously compiled by Oyendola and Chude [3]. Consistent with these ranges, the $\mathrm{Zn}$ and $\mathrm{B}$ levels were low at all of the sites, $\mathrm{Cu}$ was very low but above the critical value of 1 $\mathrm{mg} \cdot \mathrm{kg}^{-1}, \mathrm{Mn}$ was limited in the valleys and slopes but higher in the mounds, and $\mathrm{Fe}$ was well above the critical level in all of the habitats. Values of $\mathrm{Zn}(0.99-1.41$ $\left.\mathrm{mg} \cdot \mathrm{kg}^{-1}\right) \mathrm{B}\left(0.17-0.31 \mathrm{mg} \cdot \mathrm{kg}^{-1}\right)$ and $\mathrm{Cu}(1.03-1.33$ $\mathrm{mg} \cdot \mathrm{kg}^{-1}$ ) were comparable to those found in other nutrient poor environments $[19,20]$. However, in more fertile soils the levels of $\mathrm{Zn}\left(2-4 \mathrm{mg} \cdot \mathrm{kg}^{-1}\right), \mathrm{B}\left(5-8 \mathrm{mg} \cdot \mathrm{kg}^{-1}\right)$ and $\mathrm{Cu}\left(12-20 \mathrm{mg} \cdot \mathrm{kg}^{-1}\right)$ are considerable higher [21-23]. Micronutrient shortages greatly affect soil fertility and consequently constrain plant productivity, inhibit growth, and exacerbate leaf senescence $[19,24]$. Additionally, litter decomposition rates are also lower under limiting micronutrient availability, given that the process is dependent on metallomic enzymes $[25,26]$. In leached and strongly acid tropical soils, the pool of soluble $\mathrm{Fe}, \mathrm{Mn}$, and $\mathrm{Al}$ are high, which may be potentially toxic for plants $[20,27,28]$. Decreasing levels of soil $\mathrm{N}$ in the Amazon caatinga habitats, from the valleys towards mounds, was corroborated by the values of total $\mathrm{N}$, available $\mathrm{P}$, and $\mathrm{N} / \mathrm{P}$ ratio $[9,10,14]$.

Mineral nutrient composition of leaves did not follow the same pattern of availability found in the soils (Tables 1 and 2). The total level of micronutrients in the soil is determined by the original geological substrate and subsequent geological and pedogenic regimes [21], but the accumulation of a given element within plants is controlled by complex processes regulated by a network of gene products critical for uptake, binding, transportation, and sequestration [5]. The concentrations of leaf micronutrients: $\mathrm{Fe}, \mathrm{Zn}, \mathrm{B}$, and $\mathrm{Cu}$ were below the sufficiency levels $72,15-20,20-70,3-7 \mathrm{mg} \cdot \mathrm{Kg}^{-1}$, respectively, as defined by Marschner [29]. Furthermore, values of Fe, Zn, and $\mathrm{Cu}$ were at the lower end of the range previously reported in tropical acid soils: $10-2467,8-139$, and 1 $53 \mathrm{mg} \cdot \mathrm{kg}^{-1}$, respectively $[2,20,30]$. Values of B in $E$. leucantha (valley) and M. sprucei (slopes) were within a range of marginal sufficiency $\left(14-18 \mathrm{mg} \cdot \mathrm{kg}^{-1}\right)$ [31]. Conversely, species from the mounds had the lowest B. In contrast, Mn was above the sufficiency level (10-20 $\left.\mathrm{mg} \cdot \mathrm{kg}^{-1}\right)$ in all species except $P$. sordida, but below the accumulator levels of $1000 \mathrm{mg} \cdot \mathrm{kg}^{-1}$ [32]. Similarly, despite across species differences in leaf $\mathrm{Al}$ concentrations; values were much lower than $2300-3900 \mathrm{mg} \cdot \mathrm{kg}^{-1}$, which is typical for $\mathrm{Al}$ accumulator species in tropical habitats [33]. The species with the higher $\mathrm{Al}\left(49.4 \mathrm{mg} \cdot \mathrm{kg}^{-1}\right)$ was $R$. morilloi of the Rubiaceae family. This family has a large number of $\mathrm{Al}$ accumulator species in tropical environments [27]. Leaf macronutrient composition showed a pattern similar to that previously found in the same species $[11,12]$. In addition, the $\mathrm{N} / \mathrm{P}$ ratio was comparable across all sites and was less than $16.4 \mathrm{~kg} \cdot \mathrm{kg}^{-1}$, which confirmed the notion that $\mathrm{N}$ limitation overrides that of $\mathrm{P}$ in the three zones of the Amazon caatinga toposequence following the criteria outlined by Lambers [34].

Although the close relationships between macro- and micronutrients were found in this study, they are not fully understood, Fe, Mn, Zn, N, P, and Mg all have essential roles in photosynthetic leaf function. We found positive and statistically significant correlations between these micro- and macro-nutrients (Fe-P; Fe-N; Mn-Mg; Zn-N; $\mathrm{Zn}-\mathrm{P})$. Consequently, the maintenance of a balanced ac- 
cumulation of these micro- and macronutrients in leaves may have an adaptive value for growth in habitats with limited availability. Indeed, some interrelationships have been previously identified between micro- and macronutrients. For example, a nucleic acid-protein set has been correlated with concentrations of $\mathrm{P}, \mathrm{N}, \mathrm{Cu}, \mathrm{S}$, and $\mathrm{Fe}$, and structural, photosynthetic, and enzymatic sets have also been correlated with concentrations of $\mathrm{Mn}, \mathrm{Mg}, \mathrm{Ca}$, and $\mathrm{K}$ [35]. However, further studies including a wide variety of habitats and species are required for a complete understanding of this issue.

\section{Conclusions}

Based on the results of the present study, the following conclusions were drawn:

1. The soil $\mathrm{Zn}, \mathrm{B}$, and $\mathrm{Cu}$ levels were very low in all of the habitats of the Amazon caatinga toposequence.

2. The soil levels of Fe would be potentially toxic in all habitats, Mn levels may be toxic in the mounds, and Al may be toxic in valleys and slopes.

3. In all of the habitats, the leaf concentrations of $\mathrm{Cu}$, $\mathrm{B}, \mathrm{Zn}$, and Fe were below sufficiency levels, and concentrations of $\mathrm{Mn}$ and $\mathrm{Al}$ were within normal range found in non-accumulators.

4. A strong relationship between leaf micro- and macronutrients suggested the maintenance of a homeostatic nutrient composition, which would favor photosynthetic function at the leaf level. Therefore, the local distribution of species may be shaped for their abilities to maintain a balanced collection of micronutrients through roots under critical levels of available $\mathrm{Zn}, \mathrm{B}$, and $\mathrm{Cu}$ as well as the ability to exclude $\mathrm{Mn}, \mathrm{Fe}$, and $\mathrm{Al}$.

\section{Acknowledgements}

Financial support for soil and plant analysis was provided partially by DID-USB-Fondo de Trabajo-2012. Helpful discussions with Dr E. Olivares (IVIC, Caracas) during the development of this study are sincerely appreciated, as well the kind bibliographical materials provided. I thank Pedro Maquirino for his invaluable help in the field work, and to Editor and anonymous referees for suggestions to improve the manuscript.

\section{REFERENCES}

[1] B. E. Davies, "Deficiencies and Toxicities of Trace Elements and Micronutrients in Tropical Soils: Limitations of Knowledge and Future Research Needs," Environmental Toxicology and Chemistry, Vol. 16, No. 1, 1997, pp. 75-83. http://dx.doi.org/10.1002/etc.5620160108

[2] E. Olivares, G. Colonnello, E. Peña and L. Rodriguez, "Aluminum Accumulation in Nineteen Melastomataceae Species from Three Contrasting Plant Formations in Acid Soils," Journal of Plant Nutrition and Soil Science, Vol.
173, No. 3, 2010, pp. 453-460. http://dx.doi.org/10.1002/jpln.200900152

[3] E. Y. Oyinlola and V. O. Chude, "Status of Available Micronutrients of the Basement Complex Rock-Derived Alfisols in Northern Nigeria Savanna," Tropical and Subtropical Agroecosystems, Vol. 12, No. 2, 2010, pp. 229237.

http://www.veterinaria.uady.mx/ojs/index.php/TSA/articl e/view/226

[4] S. S. Merchant, "The Elements of Plant Micronutrients," Plant Physiology, Vol. 154, No. 2, 2010, pp. 512-515. doi:http:/dx.doi.org/10.1104/pp.110.161810

[5] I. Baxter, "Ionomics: Studying the Social Network of Mineral Nutrients," Current Opinion in Plant Biology, Vol. 12, No. 4, 2009, pp. 381-386. http://dx.doi.org/10.1016/j.pbi.2009.05.002

[6] K. Satismruti, N. Senthil, S. Vellaikumar, R. V. Ranjani and M. Raveendran, "Plant Ionomics: A Platform for Identifying Novel Gene Regulating Plant Mineral Nutrition," American Journal of Plant Sciences, Vol. 4, No. 7, 2013, pp. 1309-1315.

[7] R. Herrera, "Soil and Terrain Condition in the San Carlos de Rio Negro Project (Venezuela MAB-1) Study Site; Correlation with Vegetation Types," In: E. F. Brunig, Ed., Transactions of the Second International MAB-IUFRO Workshop on Tropical Rainforest Ecosystems Research (Jakarta), World Chair of Forestry, Hamburg-Reinbek, 1977, pp. 182-188.

[8] R. F. Breimer, "Some Observations on Soils in Relation to Forest Types in San Carlos de Rio Negro, Venezuela," In: R. F. Breimer, A. J. van Kekem and H. van Reuler, Eds., Guidelines for Soil Survey in Ecological Research, UNESCO, Paris, 1985, pp. 108-110.

[9] D. A. Coomes, "Nutrient Status of Amazonian Caatinga Forests in a Seasonally Dry Area: Nutrient Fluxes in Litter Fall and Analyses of Soils," Canadian Journal of Forest Research, Vol. 27, No. 6, 1997, pp. 831-839.

[10] H. Tiessen, E. Cuevas and P. Chacon, "The Role of Soil Organic Matter in Sustaining Soil Fertility," Nature, Vol. 371, No. 7464, 1994, pp. 783-785. http://dx.doi.org/10.1038/371783a0

[11] E. Cuevas and E. Medina, "Nutrient Dynamics within Amazonian Forest Ecosystems," Oecologia, Vol. 68, No. 3, 1986, pp. 466-472. http://dx.doi.org/10.1007/BF01036756

[12] M. A. Sobrado and E. Medina, "General Morphology, Anatomical Structure and Nutrient Content of Sclerophyllous Leaves of the 'Bana' Vegetation," Oecologia, Vol. 45, No. 3, 1980, pp. 341-345. doi:http://www.jstor.org/stable/4216102

[13] M. A. Sobrado, "Leaf Pigment Composition and Fluorescence Signatures of Top Canopy Leaves in Species of the Upper Rio Negro Forests," Research Journal of Botany, Vol. 6, No. 4, 2011, pp. 141-149. http://dx.doi.org/10.3923/rjb.2011.141.149

[14] M. A. Sobrado, "Leaf Characteristics, Wood Anatomy and Hydraulic Properties in Tree Species from Contrasting Habitats within Upper Rio Negro Forests in the Amazon Region," Journal of Tropical Ecology, Vol. 26, No. 2, 
2010 , pp. $215-226$ http://dx.doi.org/10.1017/S0266467409990538

[15] M. A. Sobrado, "Leaf Tissue Water Relations in Tree Species from Contrasting Habitats within the Upper Rio Negro Forests of the Amazon Region," Journal of Tropical Ecology, Vol. 28, No. 5, 2012, pp. 519-522. http://dx.doi.org/10.1017/S0266467412000454

[16] T. Sims and A. Wolfe, "Recommended Soil Testing Procedures for the Northeastern United States," Northeast Regional Bulletin No 493, Agricultural Experiment Station, University of Delaware, Delaware, 1995.

[17] R. O. Miller, "High-Temperature Oxidation: Dry Ashing," In: Y. P. Kaira, Ed., Handbook of Reference Methods for Plant Analysis, CRC, Boca Raton, 1988, pp. 53-56.

[18] M. A. Sobrado, "Leaf Characteristics and Diurnal Variation of Chlorophyll Fluorescence in Leaves of the 'Bana' Vegetation of the Amazon Region," Photosynthetica, Vol. 46, No. 2, 2008, pp. 202-207. http://dx.doi.org/10.1007/s11099-008-0033-9

[19] A. S. Lopes, "Micronutrients in Soils of the Tropics as Constraints to Food Production in the Tropics," The International Rice Research Institute, Los Baños, Laguna, 1980.

[20] M. Osaki, T. Watanabe, T. Ishizawa, C. Nilnond, T. Nuyim, T. Shinano, M. Urayama and S. J. Tuah, "Nutritional Characteristics of the Leaves of Native Plants Growing in Adverse Soils of Humid Tropical Lowlands," Plant Foods for Human Nutrition, Vol. 58, No. 2, 2003, pp. 93-115. http://dx.doi.org/10.1023/A:1024415203690

[21] Y. Jiang, Y. G. Zhang, D. Zhou, Y. Qin and W. J. Liang, "Profile Distribution of Micronutrients in an Aquatic Brown Soil as Affected by Land Use," Plant Soil and Environment, Vol. 55, No. 11, 2009, pp. 468-476.

http://www.agriculturejournals.cz/publicFiles/12160.pdf

[22] V. Srivasan, S. Hanza, K. S. Krishnamurthy and C. K. Thankamani, "Threshold Level of Soil Zinc for Optimum Production of Ginger (Zingiber officinale Rosc.)," Journal of Spices and Aromatic Crops, Vol. 13, No. 1, pp. 5557.

http://220.227.138.214:8080/dspace/bitstream/123456789 /129/1/Vol.+XIII+No.1+\%2855-57\%29.pdf

[23] R. O. Nable, G. S. Bañuelos and G. Paull, "Boron Toxicity," Plant and Soil, Vol. 193, No. 1-2, 1997, pp. 181-198. http://dx.doi.org/10.1023/A:1004272227886

[24] Y. L. Feng, Y. B. Lei and Z. Li, "Micronutrients Deficiencies Accelerate Leaf Senescence in Amomum villosum," Botanical Studies, Vol. 53, No. 3, 2012, pp. 345-352. http://ejournal.sinica.edu.tw/bbas/content/2012/3/Bot53307.pdf

[25] M. Kaspari, M. N., Garcia, K. H. Harms, M. Santana, S. J. Wright and J. B. Yavitt, "Multiple Nutrients Limit Litterfall and Decomposition in Tropical Forests," Ecology Letters, Vol. 11, No. 1, 2008, pp. 35-43. http://dx.doi.org/10.1111/j.1461-0248.2007.01124.x
[26] J. S. Powers and S. Salute, "Macro- and Micronutrients Effects on Decomposition of Leaf Litter from Two Tropical Tree Species: Inferences from a Short-Term Laboratory Incubation," Plant and Soil, Vol. 346, No. 1-2, 2011, pp. 245-257.

http://dx.doi.org/10.1007/s11104-011-0815-x

[27] S. Jansen, M. R. Broadley, E. Robbrecht and E. Smets, "Aluminium Hyperaccumulation in Angiosperms: A Review of Its Phylogenetic Significance," The Botanical Review, Vol. 68, No. 2, 2002, pp. 235-269. http://dx.doi.org/10.1663/0006-8101(2002)068[0235:AHI $\mathrm{AAR}] 2.0 . \mathrm{CO} ; 2$

[28] N. P. Qafoku, E. van Ranst, A. Noble and G. Baert, "Variable Charge Soils: Their Mineralogy, Chemistry and Management," Advances in Agronomy, Vol. 84, 2004, pp. 159-215.

http://dx.doi.org/10.1016/S0065-2113(04)84004-5

[29] H. Marschner, "Mineral Nutrition of Higher Plants," Academic Press, London, 1995.

[30] E. Olivares, M. Benítez, E. Peña and G. Colonnello, “Aluminum Accumulation and Nutrients in Pterolepis glomerata, Desmoscelis villosa and Rhynchanthera grandiflora in Palm Swamp Communities," Botany, Vol. 91, No. 3, 2013, pp. 202-208.

[31] G. Liakopoulos and G. Karabourniotis, "Boron Deficiency and Concentration and Composition of Phenolic Compounds in Olea europaea Leaves: A Combined Growth Chamber and Field Study," Tree Physiology, Vol. 25, No. 3, 2005, pp. 307-315.

http://dx.doi.org/10.1093/treephys/25.3.307

[32] S. D. Bidwell, I. E. Woodrow, G. N. Bataianoff and J. Sommer-Knudsen, "Hyperaccumulation of Manganese in the Rainforest Tree Austromyrtus bidwillii (Myrtaceae) from Queensland, Australia," Functional Plant Biology, Vol. 29, No. 7, 2002, pp. 899-905. http://dx.doi.org/10.1071/PP01192

[33] F. Metali, K. A. Salim and D. F. R. P. Burslem, "Evidence of Foliar Aluminium Accumulation in Local, Regional and Global Datasets of Wild Plants," New Phytologist, Vol. 193, No. 3, 2012, pp. 637-649.

http://dx.doi.org/10.1111/j.1469-8137.2011.03965.x

[34] H. Lambers, M. C. Brundrett, J. A. Raven and S. D. Hopper, "Plant Mineral Nutrition in Ancient Landscapes: High Plant Species Diversity on Infertile Soils Is Linked to Functional Diversity for Nutritional Strategies," Plant and Soil, Vol. 334, No. 1-2, 2010, pp. 11-31. http://dx.doi.org/10.1007/s11104-010-0444-9

[35] T. Watanabe, M. R. Broadley, S. Jansen, P. J. White, J. Takada, K. Satake, T. Takamatsu, S. J. Tuah and M. Osaki, "Evolutionary Control of Leaf Elements Composition in Plants," New Phytologist, Vol. 174, No. 3, 2007, pp. 516523. http://dx.doi.org/10.1111/j.1469-8137.2007.02078.x 